Received: 2010.06 .17
Accepted: 2010.08 .27
Published: 2011.04 .01
Authors' Contribution:
A Study Design
B Data Collection
C Statistical Analysis
D Data Interpretation
E Manuscript Preparation
F Literature Search
G Funds Collection

Background:

Material/Methods:

Results:

Conclusions:

key words:

Full-text PDF:

Word count:

Tables:

Figures:

References:

Author's address:

\section{Access to biologic treatment for rheumatoid arthritis in Central and Eastern European (CEE) countries}

\author{
Ewa Orlewska ${ }^{1 \mathrm{ABCDBF}}$, Ioan Ancuta ${ }^{2 \mathrm{~B}}$, Branimir Anic $^{3 \mathrm{~B}}$, Catalin Codrenau ${ }^{4 \mathrm{~B}}$,
} Nemanja Damjanov ${ }^{5 \mathrm{~B}}$, Predrag Djukic ${ }^{6 \mathrm{~B}}$, Ruxandra lonescu ${ }^{7 \mathrm{~B}}$, Lubomir Marinchev ${ }^{8 \mathrm{~B}}$,

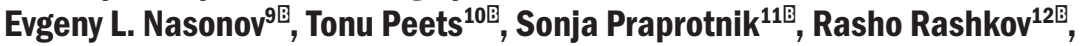
Jana Skoupa ${ }^{13 \mathrm{E}}$, Witold Tlustochowicz ${ }^{14 \mathrm{E}}$, Malgorzata Tlustochowicz ${ }^{14 \mathrm{E}}$, Matija Tomsic ${ }^{11 \mathrm{E}}$, Tiina Veldi ${ }^{15 \mathrm{E}}$, Jelena Vojinovic ${ }^{16 \mathrm{E}}$, Piotr Wiland ${ }^{17 \mathrm{~B}}$

${ }^{1}$ Center for Pharmacoeconomics, Warsaw, Poland

${ }^{2}$ Clinical Institute Ion Catacuzino, Bucharest, Romania

${ }^{3}$ Clinical Hospital Zagreb, Zagreb, Croatia

${ }^{4}$ Methodical Rheumatology Center Prof. Dr. Ion Stoia, Bucharest, Romania

${ }^{5}$ Institute of Rheumathology, Beograd, Serbia

${ }^{6}$ Consultant for Health Economics and Management, Beograd, Serbia

${ }^{7}$ University of Medicine, Saint Maria UMF Carol Davila Hospital, Bucharest, Romania

${ }^{8}$ University Hospital St. Ivan Rilski, Sofia, Bulgaria

${ }^{9}$ Rheumatology Institute of RAMS, Moscow, Russia

${ }^{10}$ Department of Rheumatology, East Tallinn Central Hospital, Tallinn, Estonia

${ }^{11}$ University Medical Centre, Ljubljana, Slovenia

${ }^{12}$ University Hospital St. Ivan Rilski, Sofia, Bulgaria

${ }^{13}$ Pharma Projects s.r.o., Prague, Czech Republic

${ }^{14}$ Military Medical Institute, Warsaw, Poland

${ }^{15}$ East Tallin Central Hospital, Tallin, Estonia

${ }^{16}$ Klinieki Centar Nis, Nis, Serbia

${ }^{17}$ Medical University of Wroclaw, Wroclaw, Poland

Source of support: This research was financed by Roche and carried out by the Centre for Pharmacoeconomics, Warsaw, Poland in cooperation with clinical experts from selected CEE countries

\section{Summary}

The aim of this study was to assess and compare patients' access to biologic anti-RA drugs in selected Central and Eastern European (CEE) countries and to analyze the determinants of differences between countries.

This is a multi-country survey study, based on a combination of desk research and direct contact with national RA stakeholders. Data was collected using a pre-defined questionnaire. Affordability was measured using an affordability index, calculated comparing the index of health care expenditures to the price index, using Poland as an index of 1.

The percentage of patients on biologic treatment in 2009 was highest in Hungary ( $5 \%$ RA patients on biologic treatment), followed by Slovenia (4.5\%), Slovakia (3.5\%), Czech Republic (2.92\%), Romania (2.2\%), Estonia (1.8\%), and Croatia, Serbia, Poland (below 1.5\%). Infliximab, etanercept, adalimumab and rituximab were included in the reimbursement system in all countries, but abatacept and tocilizumab were included only in Slovakia. In Slovenia, public payer covered $75 \%$ of the price, and $25 \%$ is covered by supplementary health insurance; in Bulgaria public payer covered $50 \%$ of etanercept and adalimumab costs, and $75 \%$ of rituximab cost. In other countries, biologic drugs are reimbursed at $100 \%$. Affordability index for biologic drugs was the lowest in Slovenia (0.4). In each country national guidelines define which patients are eligible for biologic treatment. Disease Activity Score (DAS28) of over 5.1 and failure of 2 or more disease-modifying anti-RA drugs, including methotrexate, are commonly used criteria.

The most important factors limiting access to biologic anti-RA treatment in the CEE region are macroeconomic conditions and restrictive treatment guidelines.

rheumatoid arthritis • biologic treatment • guideline • health services accessibility

http://www.medscimonit.com/fulltxt.php?ICID=881697

5438

7

6

31

Ewa Orlewska, Center for Pharmacoeconomics, Warsaw, Poland, e-mail: ewaorlewska@g02.pl 


\section{BACKGROUND}

The introduction of biologic drugs for treatment of rheumatoid arthritis (RA) was one of the most striking advances in medical science and health care in the last decade. It is an interesting area of study, not only due to the importance of the issues in question, but also as an example of how society handles the complicated process of introducing new and costly health care technologies. It is important that patients are certain they are receiving the best treatment possible, based on clinical evidence and experience, rather than the financial situation. However, the prospects for people diagnosed with RA are substantially influenced by geographical location, due to different macro-economic conditions [1]. By providing a snapshot of the current situation in Central and Eastern European (CEE) countries, this study aimed to assess and compare patients' access to new RA drugs in selected CEE countries, and to analyze the determinants of differences between countries as a basis for discussion of how patients' access to new and innovative treatments can be improved. The study highlights best practices across CEE countries, together with stakeholders' priorities and recommendations, with the aim of raising standards of care for people living with RA.

\section{MATERIAL AND Methods}

This research project was a multi-country survey study. The following countries were included in the analysis: Bulgaria, Croatia, Czech Republic, Estonia, Hungary, Poland, Romania, Russia, Serbia, Slovakia, and Slovenia. The study was performed between March 2009 and March 2010, based on desk research and direct contact with national RA stakeholders.

\section{Data collection method}

Data was collected using a pre-defined set of questions covering the following categories:

- Health care system characteristics,

- epidemiology of RA,

- RA care structure,

- biological therapy of RA.

Both closed-ended questions (respondents' answers were limited to a fixed set of responses) and open-ended questions (no options or predefined categories were suggested) were included.

\section{Desk research}

Relevant information was gathered from each country through a range of sources including government and patients' association websites, published scientific literature and media reports. The following data sources were used:

- national statistics, government reports,

- large epidemiological trials (published and unpublished),

- registries, naturalistic studies, claims data,

- market research data,

- published information on current treatment patterns,

- official price lists of drug and treatment costs.

\section{Stakeholder interviews}

In the second phase, in each country, interviews were carried out with 3 to 4 national stakeholders representing the medical community, patients' organizations and institutions responsible for health care expenditures. Stakeholder representatives were identified based on the individual's knowledge of and/or involvement in national RA policies and initiatives. Interviews were carried out in the interviewee's native language.

\section{Assessment of affordability}

Affordability was measured using an affordability index, calculated comparing the relative health care expenditures per capita (as and index) to the relative price index, using Poland as the basis. A higher index indicates more difficulties to afford goods and services.

\section{Assessment of accessibility}

Accessibility to biologic drugs for selected countries was assessed by using:

a. the number of patients receiving biological therapy at the time of the survey in each country, as well as on the proportion of RA patients they represent,

b. sales data (number of packs of medication per 1000 inhabitants) as a marker of actual utilization, comparison of the differences in time of the first entry to the health care system, the increase in utilization after inclusion into the reimbursement system and the utilization at the end of year 2008. Furthermore, accessibility was valued in relation to new drug uptake affordability of different health care systems.

\section{RESULTS}

\section{Characteristics of health care system}

In Central and Eastern Europe, health care systems have evolved in different ways from the centralized systems inherited from the communist era. However, common trends and challenges remain in the region. The relatively low health care spending, measured both in absolute terms and as a percentage of Gross Domestic Product (GDP), is a universal problem. In all CEE countries, except for Slovenia, the overall spending on health care falls considerably below spending levels for the 15 pre-2004 EU members. Total expenditure on health care per capita (USD at PPP) in 2007 ranged from 679 in Bulgaria and 754 in Romania, to approximately 1500 in the Czech Republic and Hungary, and 2123 in Slovenia (Table 1), compared to 2694 on average in EU-15.

In all 11 countries, health care is largely publicly financed (Table 1). Social health insurance funded through employment-related premiums is the dominant model in the region. In Russia, despite the intention to shift to an insurance-based system, federal and regional budgets still administer about $60 \%$ of public health care expenditure. Private insurance in the CEE region is of the supplementary type rather than the comprehensive "substitute" type. Only in Slovakia are for-profit publicly traded and foreign insurance providers 
Table 1. Health care expenditure (Source: World Health Organization, 2009).

\begin{tabular}{cccccccccccc}
\hline & Bulgaria & Croatia & $\begin{array}{c}\text { Czech } \\
\text { Rep }\end{array}$ & Estonia & Hungary & Poland & Romania & Russia & Serbia & Slovakia Slovenia \\
\hline $\begin{array}{c}\text { Total expenditure on health } \\
\text { (THE) as\% of GDP }\end{array}$ & 7.3 & 8.1 & 6.9 & 5.4 & 8.2 & 6.0 & 5.8 & 5.4 & 8.4 & 7.0 & 8.2 \\
\hline $\begin{array}{c}\text { General government } \\
\text { expenditures on health } \\
\text { (GGHE) as\% of the THE }\end{array}$ & 57.2 & 81.4 & 87.6 & 78.2 & 71.2 & 69.9 & 71.9 & 64.2 & 74 & 71.2 & 72.3 \\
\hline $\begin{array}{c}\text { Private sector expenditures } \\
\text { on health (PvtHE) as\% of } \\
\text { the THE }\end{array}$ & 42.8 & 18.6 & 12.4 & 21.8 & 28.8 & 30.1 & 28.1 & 35.8 & 26 & 28.8 & 27.7 \\
\hline $\begin{array}{c}\text { Social security founds as\% } \\
\text { of GGHE }\end{array}$ & 63.0 & 88.3 & 91.4 & 83 & 91.9 & 83.4 & 80.3 & 38.7 & 92.9 & 88.7 & 91.7 \\
\hline $\begin{array}{c}\text { Prepaid and risk-pooling } \\
\text { plans as\% of PvtHE }\end{array}$ & 0.8 & 5.9 & 1.8 & 1.4 & 4.6 & 1.8 & 16.4 & 9.6 & & 0.0 \\
\hline $\begin{array}{c}\text { Private housholds' out-of } \\
\text { pocket payment as\% of } \\
\text { PvtHE }\end{array}$ & 97.3 & 94.1 & 95.6 & 93.6 & 78.6 & 85.7 & 82.5 & 83 & 86.3 & 80.9 & 42.9 \\
\hline $\begin{array}{c}\text { Total expenditure on } \\
\text { health/capita USD at } \\
\text { exchange rate }\end{array}$ & 345 & 689 & 1108 & 835 & 1126 & 668 & 459 & 491 & 467 & 971 & 1855 \\
\hline $\begin{array}{c}\text { Total expenditure } \\
\text { on health/capita at } \\
\text { international USD rate }\end{array}$ & 754 & 1035 & 1579 & 1091 & 1533 & 965 & 679 & 794 & 899 & 1403 & 2123 \\
\hline
\end{tabular}

Table 2. Indicators characterizing resources for health care delivery.

\begin{tabular}{|c|c|c|c|c|c|c|c|c|c|c|c|}
\hline & Bulgaria & Croatia & Czech Rep & Estonia & Hungary & Poland & Romania & Russia & Serbia & Slovakia & Slovenia \\
\hline $\begin{array}{c}\text { Physicians per } \\
100,000\end{array}$ & 319 & 376 & 420 & 330 & 320 & 225 & 195 & 484 & 272 & 310 & 240 \\
\hline $\begin{array}{l}\text { Hospital beds per } \\
100,000\end{array}$ & 588 & 549 & 827 & 560 & 720 & 464 & 650 & 1125 & 557 & 880 & 483 \\
\hline $\begin{array}{c}\text { CT scanners per } \\
100,000\end{array}$ & & & 1.32 & 0,38 & 0.73 & 0.97 & 0.255 & 0.5 & 0.5 & 1.37 & 0.95 \\
\hline $\begin{array}{c}\text { MRI units per } \\
100,000\end{array}$ & & & 0.44 & 0,37 & 0.28 & 0.27 & 0.005 & & & 0.57 & \\
\hline $\begin{array}{c}\text { Outpatient } \\
\text { contacts per } \\
\text { person }\end{array}$ & 5.9 & 6.05 & 14.58 & 6.8 & 12.9 & 7.4 & 5.6 & & 7.42 & 12.3 & 6.8 \\
\hline $\begin{array}{c}\text { Inpatient care } \\
\text { admissions per } \\
1000\end{array}$ & 131 & 168 & 220 & 192 & 240 & 187 & 242.6 & 290 & 155.2 & 164 & 95 \\
\hline $\begin{array}{l}\text { Average length of } \\
\text { stay in hospital }\end{array}$ & 8.3 & 7.54 & 7.1 & 6.9 & 5.6 & 6.2 & 7.0 & 14.2 & 9.6 & 6.2 & 6.8 \\
\hline $\begin{array}{l}\text { Waiting time for } \\
\text { arthroplasty }\end{array}$ & & & & & $\begin{array}{c}90-730 \\
\text { days }\end{array}$ & $\begin{array}{l}1,200 \\
\text { days }\end{array}$ & & $\begin{array}{l}180 \\
\text { days }\end{array}$ & $\begin{array}{l}912 \\
\text { days }\end{array}$ & & $\begin{array}{c}522-763 \\
\text { days }\end{array}$ \\
\hline
\end{tabular}

allowed to compete with the public sector funds. Out-ofpocket payments take the form of co-payments for goods and services covered by the insurance scheme or direct payment to private or public providers for services outside of the yearly framework contracts. Slovakia and Slovenia are the only countries in the region that have adopted formal co-payments for a wide range of health care services. In Slovenia, voluntary health insurance covers co-payments for 
Table 3. Comparison of affordability index of selected health care services.

\begin{tabular}{|c|c|c|c|c|c|c|c|c|c|c|}
\hline & & Czech & Estonia & Hungary & Poland & Romania & Russia & Serbia & Slovakia & Slovenia \\
\hline \multirow{2}{*}{$\begin{array}{l}1 \text { day intensive care } \\
\text { unit cost }\end{array}$} & $1^{\text {st }}$ level & 0.23 & 0.09 & 0.16 & 1 & NA & 0.32 & 0.11 & NA & 1.66 \\
\hline & $3^{\text {rd }}$ level & 0.31 & 0.86 & & & & & & & \\
\hline \multicolumn{2}{|c|}{1 day rheumatological unit cost } & 0.43 & 0.64 & 0.33 & 1 & NA & 1.62 & 0.41 & NA & 0.98 \\
\hline \multirow{3}{*}{ GP consultation } & $\begin{array}{cc}\text { Complex } & 60 \\
\text { examination } & \text { min. }\end{array}$ & 1.53 & 0.33 & 0.41 & 1 & 1.69 & 2.25 & 0.52 & NA & 0.32 \\
\hline & $\begin{array}{cc}\text { Targeted } & 15 \\
\text { examination } & \text { min. }\end{array}$ & 0.4 & & & & & & & & \\
\hline & $\begin{array}{c}\text { Control } \\
\text { examination }\end{array}$ & 0.27 & & & & & & & & \\
\hline \multirow{2}{*}{$\begin{array}{c}\text { Specialist } \\
\text { consultation } \\
\text { (rheumatologist) }\end{array}$} & $\begin{array}{cc}\text { Complex } & 60 \\
\text { examination } & \text { min. }\end{array}$ & 0.49 & 0.8 & 0.08 & 1 & 0.46 & 0.97 & 0.19 & NA & 0.41 \\
\hline & $\begin{array}{cc}\text { Control } & 15 \\
\text { examination } & \text { min. }\end{array}$ & 0.43 & 0.29 & & 1 & & & & & \\
\hline \multicolumn{2}{|c|}{ X-ray examination (hand and foot) } & 0.2 & 0.44 & 0.28 & 1 & 0.29 & 2.53 & 0.12 & NA & 0.77 \\
\hline \multicolumn{2}{|c|}{ Gastroscopy } & 0.22 & 0.42 & 0.15 & 1 & 0.12 & 1.88 & 0.21 & NA & NA \\
\hline
\end{tabular}

the benefits within the compulsory health insurance package, as well as complementary and supplementary benefits which are not covered by compulsory health insurance.

Indicators characterizing resources for health care delivery show that there is significant variation across CEE countries in the supply and regulation structure of health care (Table 2). The Russian health care system, with 484 physicians (of which only $22.5 \%$ are GPs) and 1125 hospital beds per 10,000 population, 290 inpatient care admissions per 1 $000 /$ year, and average length of hospital stay of 14.2 days, still reflects the tendency to over- rely on specialist treatment and hospitalization. In contrast, Slovenia has approximately 240 physicians and 483 hospital beds per 100,000 inhabitants, 95 inpatient care admissions per 1000/year and average length of hospital stay of 6.8 days. The number of outpatient contacts is the highest in the Czech Republic, Hungary and Slovakia (14.58, 12.9 and 12.3 person/year, respectively). The Czech Republic and Slovakia have the highest number of CT scanners and MRI units per 100,000 inhabitants. Length of waiting lists varies by country; from a minimum of 90 days for hip arthroplasty in Hungary (730 days in university clinics), to a maximum of 1,200 days in Poland (Table 2).

Absolute and relative prices of health care services vary greatly among CEE countries. For instance, the absolute unit cost of X-ray examination (hand and foot) in Romania was $20 \%$, in Hungary $48 \%$, and in Slovenia $214 \%$ of the costs in Poland. In Russia, 1 day of intensive care unit costs are approximately 2.5 times the cost of gastroscopy, while in Estonia this ratio is 22:1. However, in some countries (eg, the Czech Republic, Hungary and Poland) relative costs are similar. Affordability index for selected health care services, using Poland as an index of 1 , is presented in Table 3 . A higher index indicates more difficulties in affordability of goods and services. The analysis shows that only Russia

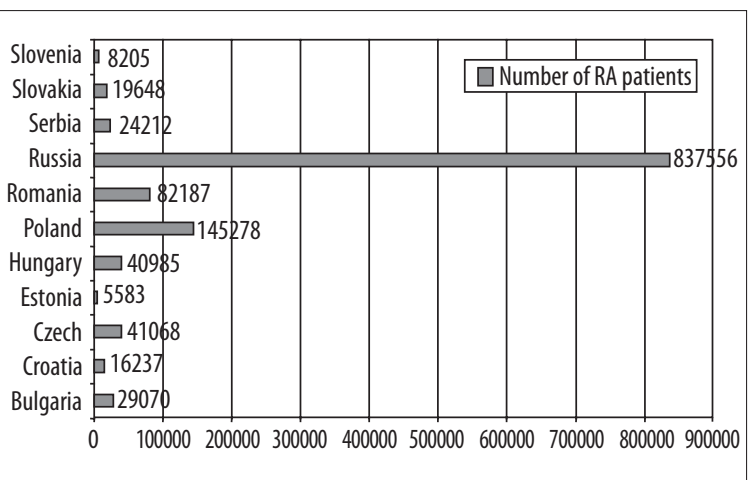

Figure 1. Number of RA patients.

has affordability of health care services generally lower than Poland.

\section{Epidemiology of RA}

An estimate of the number of RA patients in different countries was difficult to determine. Published studies have been performed in different geographic areas within countries or have included different age groups. For example, epidemiological studies performed in the Czech Republic [2], Estonia [3] and Hungary [4] covered populations above ages 16, 20, and 14, respectively, although some did not include patients above age 65 [4]. The global prevalence of RA has been estimated at $0.5-1.0 \%$. According to a population- based study conducted in Hungary, the prevalence in the $14-65$ age group was $0.37 \%$ in total $(0.23 \%$ in women, and $0.48 \%$ in men), and $50 \%-55 \%$ of the RA patients were of working age [4]. The RA prevalence rate was $0.2 \%$ (men) and $0.5 \%$ (women) in Romania, $0.61 \%$ in the Czech Republic [2], and $0.46 \%$ in Estonia [3]. According to rheumatology Key Opinion Leaders (KOLs), the RA prevalence 
Table 4. RA care structure (number per 1,000 inhabitants).

\begin{tabular}{cccccccccc}
\hline & Bulgaria & Czech & Croatia & Estonia & Hungary & Poland & Serbia & Slovakia & Slovenia \\
\hline $\begin{array}{c}\text { Hospital beds in } \\
\text { rheumatology } \\
\text { departments }\end{array}$ & 0.25 & 0.01 & NA & 0.04 & 0.1 & 0.064 & 0.03 & 0.02 & NA \\
\hline $\begin{array}{c}\text { Specialists in } \\
\text { rheumatology }\end{array}$ & 0.013 & 0.011 & 0.0054 & 0.04 & 0.045 & NA & 0.015 & NA & 0.01 \\
\hline $\begin{array}{c}\text { Rheumatology out- } \\
\text { patient clinic }\end{array}$ & NA & 0.15 & 0.0034 & 0.009 & 0.016 & NA & 0.015 & 0.017 & 0.004 \\
\hline $\begin{array}{c}\text { Rehabilitation } \\
\text { entres }\end{array}$ & NA & 0.005 & 0.0018 & 0.01 & 0.24 & 0.0067 & 0.0008 & NA & NA \\
\hline
\end{tabular}

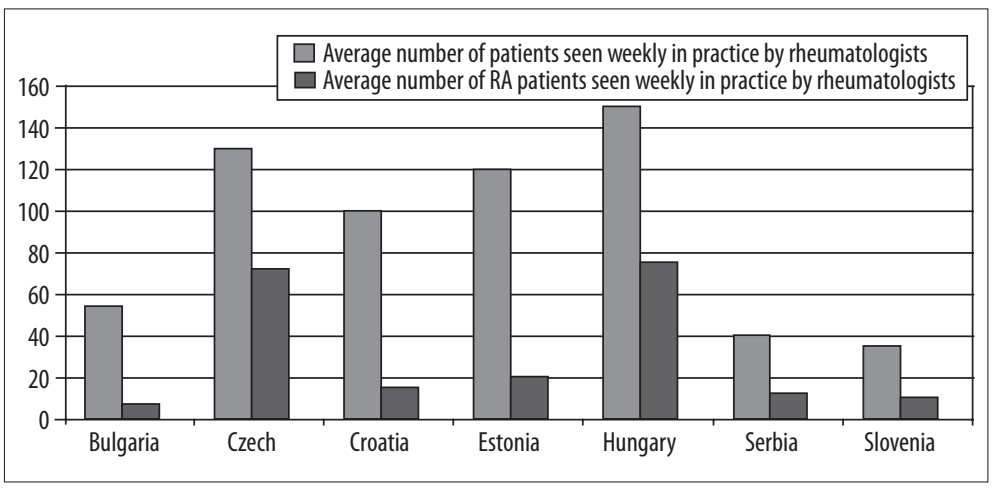

Figure 2. Number of patients seen weekly in practice by rheumatologists in several CEE countries. rate in Russia was $0.68 \%$, and only $38 \%$ (314,000 patients.) were officially registered as RA patients. In comparison to the general population, the RA population is characterized by lower income (RUB 7,000 per month) and higher unemployment (50\%). The risk of early retirement due to RA was about $70 \%$, and the average number of work-loss days per RA case was 45 each year. After 20 years from onset of first RA symptoms, approximately $90 \%$ of patients become disabled.

Figure 1 presents the estimated number of RA patients in each country. As most studies cover the adult population, the results presented in this report were calculated for the above 18 age group.

\section{RA care structure}

Rheumatoid arthritis is not a priority in the health policy of the CEE region. In Bulgaria and Romania there are no national standards for RA care. In other countries, National Rheumatologists Societies issue national standards for RA care, but their implementation is not always monitored. In Bulgaria, Croatia, Estonia, Romania and Slovenia there are no governmental institutions for RA. In other countries, national institutes of rheumatology and regional rheumatology centers are the guarantors of highly professional RA care. In all countries except Romania, patients' advocacy groups have established associations. With regard to the geographic distribution of RA care institutions and providers, basic supply-side indicators, such as number of beds, specialists, etc. per 1,000 population reveal significant variations among individual CEE countries (Table 4). Bulgaria has the highest rate of hospital beds in rheumatology departments in comparison to other CEE countries; the Czech Republic has the highest rate of rheumatology out-patient clinics; Hungary has the highest rate of rehabilitation centers and specialists in rheumatology (Table 4). The average Bulgarian rheumatologist sees a mean of 54 patients overall and 7 RA patients each week, while in Hungary the corresponding figures are as high as 150 and 75 (Figure 2), according to KOLs. Prior to receiving secondary or tertiary care, all RA patients are required to obtain referrals from their GPs (first contact physicians). RA diagnosis is performed mainly by rheumatologists and less frequently by other specialist, who are later responsible for treatment and monitoring. Rehabilitation is performed in specialized rehabilitation centers.

\section{Costs of RA}

The published literature on the costs of RA in the CEE region does not give a clear picture, as studies were performed in only 2 countries (Hungary and Serbia) [5,6]. Moreover, published studies are not consistent in their approach, samples, and data included in the analysis.

A Hungarian cross-sectional, multicenter study [5] was performed on a group of 257 RA patients $(86 \%$ female, mean age 55 years) in 2004. Two patients received biologic treatment, $88 \%$ were given disease-modifying drugs, and oral corticosteroids were used by $48 \%$. The disease duration was 9.06 years, mean Disease Activity Score was 5.09 (SD 1.42 ), and mean HAQ was 1.38 (SD 0.76). The average total cost amounted to a mean of 4,173 (SD 3,379) Euro/patient/year (direct cost $45 \%$, indirect cost $55 \%$ ). Costs correlated significantly with $H A Q$ results $(\mathrm{R}=0.382)$. 


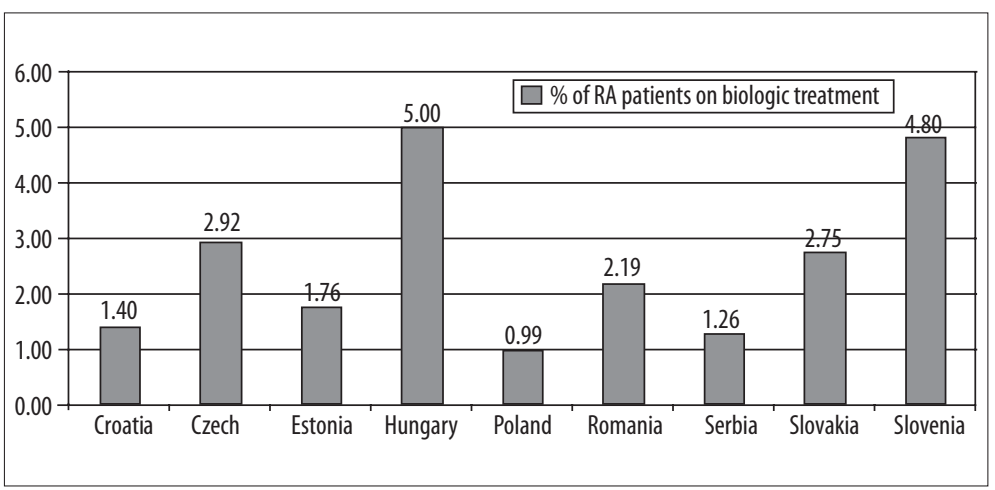

Figure 3. Percentage of RA patients on biologic treatment.

When matching Hungarian results with cost-of-illness studies using the OMERACT cost matrix, the amount of total costs in Hungary is roughly equivalent to the direct costs reported in France [7] and the Netherlands [8] (4,000 and 5,028 Euro/patient/year, respectively). In Belgium, direct costs reported for late RA (disease duration 12.5 yrs) were even higher - 9,946 Euro/patient/year [9]. In Germany, direct costs were similar to the Hungarian data (2,312 Euro), but indirect costs were much higher (for sick-leave 2,835 Euro/patient/year, for a disability pension 8,358 Euro/patient/year) [10]. The analysis of cost domains revealed that lower unit costs and average gross wages in Hungary are the main factors determining the differences. Non-medical direct costs are also strongly influenced by alterations in health care consumption rates due to disability. In France, use of formal in-home care was higher $(12.6 \%$ vs. $0.4 \%$ in Hungary), while in Hungary informal care was used more frequently $(50.2 \%)$. Mean cost of institutionalization due to RA was 222 Euro/patient/year in France, while this type of care was did not appear in the Hungarian sample.

A Serbian study [6] provided only direct cost data - RA-related health care services, materials and prescription consumed by 12 patients during 1 year (2008). All patients were female, 45-63 years old (mean 52.3), with disease duration of mean $7.4 \pm 1.9$ years; no patients received biological therapy. The average total direct costs reached 2,509 (SD 590.6) Euro/patient/ year, and was higher than in Hungary (1,878 Euro/patient/ year), but comparable to costs reported in Germany [10].

\section{Biologic therapy for RA}

Biologic treatments for RA have been introduced in the CEE region at different times and in different sequences of use. The first biologic treatments for RA, infliximab and etanercept, were introduced in 1999 and 2000 in the Czech Republic, Hungary, Poland, Romania and Slovakia; in 2000 and 2001 in Bulgaria; in 2003 and 2001 in Slovenia; in 2004 in Estonia; in 2003 and 2006 in Croatia; in 2005 and 2008 in Serbia; and in 2009 and 2001 in Russia. Adalimumab was registered in 2003 in the Czech Republic, Hungary, Poland, Romania and Slovakia; in 2004 in Bulgaria, Estonia and Slovenia; in 2005 in Croatia; in 2006 in Russia; and in 2008 in Serbia. In all countries except Croatia, rituximab has been approved for RA during 2006-2009. Most recently, in 2009, tocilizumab was registered as an option for RA treatment. Anakinra was registered in Hungary, Poland, Slovakia (in 2002); Slovenia (in 2004); and Estonia (in 2005). Abatacept was registered in the Czech Republic and Slovakia in 2007, and in Russia in 2009.

\section{Access to biologic treatment of RA}

In order to describe access to RA biologic treatments, the information on the number of patients actually treated in each country, as well as on the proportion of RA patients those represent, was required. However, such data are not readily available. Information on absolute numbers of patients receiving biologic treatment has been derived from registries or insurance fund databases in 9 countries (Czech Republic, Croatia, Estonia, Hungary, Poland, Serbia, Slovakia, Romania and Slovenia). In 2009 the highest number of RA patients who have received at least 1 dose of treatment with biologic drugs was in Hungary (2,048 patients), followed by Romania (1,800 patients), Poland $(1,443)$ and Czech Republic $(1,200)$. As the absolute number of patients does not provide any comparison due to the fact that populations and prevalence differ between countries, we calculated the proportion of patients on treatment, based on country-specific epidemiological indicators (adult population and RA prevalence rate). Results of this comparison show that in 2009 the clear front-runner was Hungary ( $5 \%$ of RA patients on biologic treatment), followed by Slovenia (4.5\%), Slovakia (3.5\%), and the Czech Republic (2.92\%). In Romania and Estonia the average usage was around $2 \%$ (2.2\% and $1.8 \%$, respectively), and in Croatia, Serbia and Poland it was below 1.5\% (1.4\%, 1.3 and $1 \%$, respectively) (Figure 3). An analysis of drug use revealed further differences among countries, which reflects national preferences and priorities. Croatia appears to have a clear preference for infliximab over etanercept and adalimumab, while Hungary, Czech Republic, Slovakia and Slovenia seem to give priority to etanercept and adalimumab over infliximab. In Poland, similar proportions of patients are treated with etanercept $(38 \%)$ and infliximab (34\%), while adalimumab is used in only $8 \%$ of patients. In Serbia, only 1 TNF-inhibitor, etanercept, is used. Differences between etanercept and infliximab use may reflect preferences for hospital products in those countries, or may be the consequence of restricted indications. For example, in Poland treatment must be initiated with infliximab, which is the least expensive drug, while in Slovenia infliximab is indicated only as the second-line treatment. There are also specific barriers to prescribing IV biologic anti-RA drugs in Slovenia: hospital drugs are reimbursed only for a limited number of patients (fixed budget for a given year). The relatively low use of adalimum$\mathrm{ab}$ in Poland can be explained by the fact that adalimumab is indicated as a second-line anti-TNF treatment only. In Slovakia, adalimumab is used as a first-line treatment, and in other countries as both first- or second-line treatment. Rituximab is indicated as a treatment option after failure 


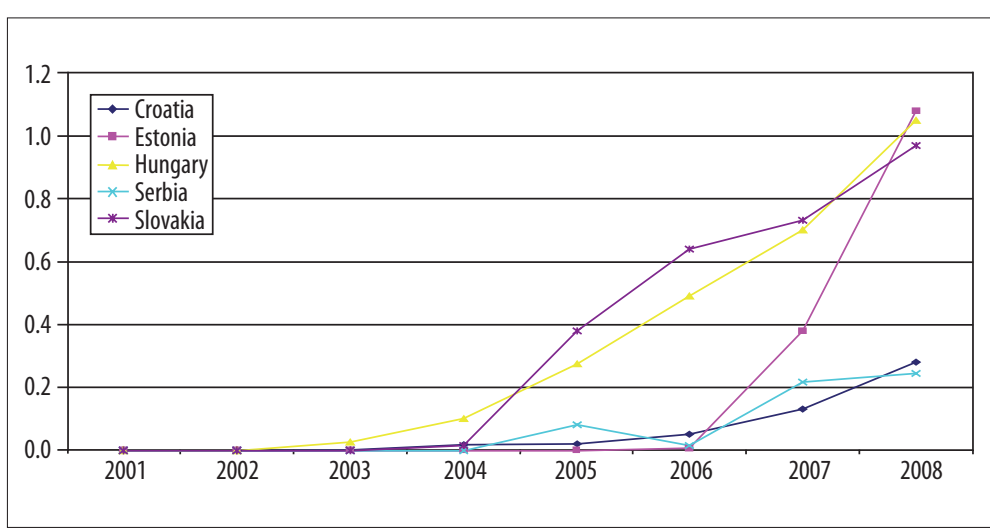

Figure 4. Etanercept in selected CEE countries: number of pack per 1000 inhabitants.

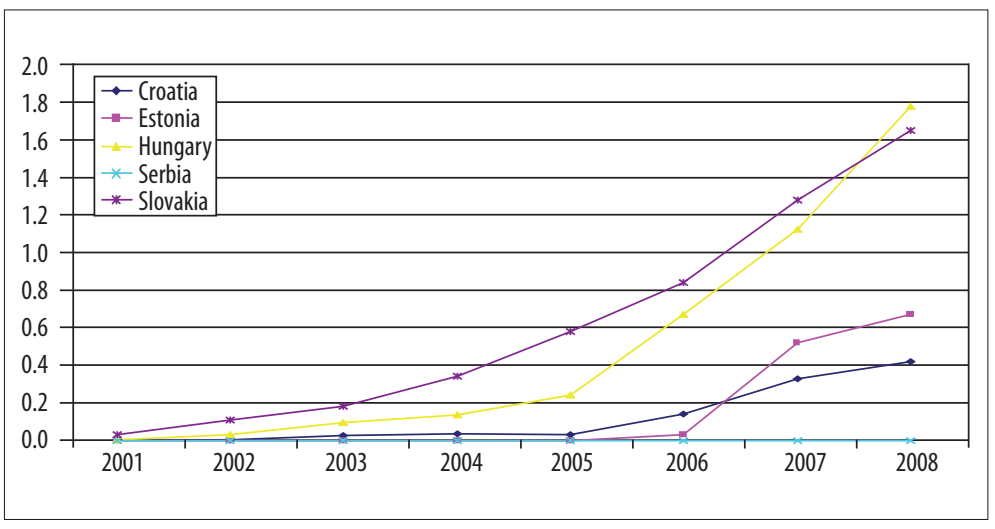

Figure 5. Infliximab in selecetd CEE countries: number of pack per 1000 inhabitants.

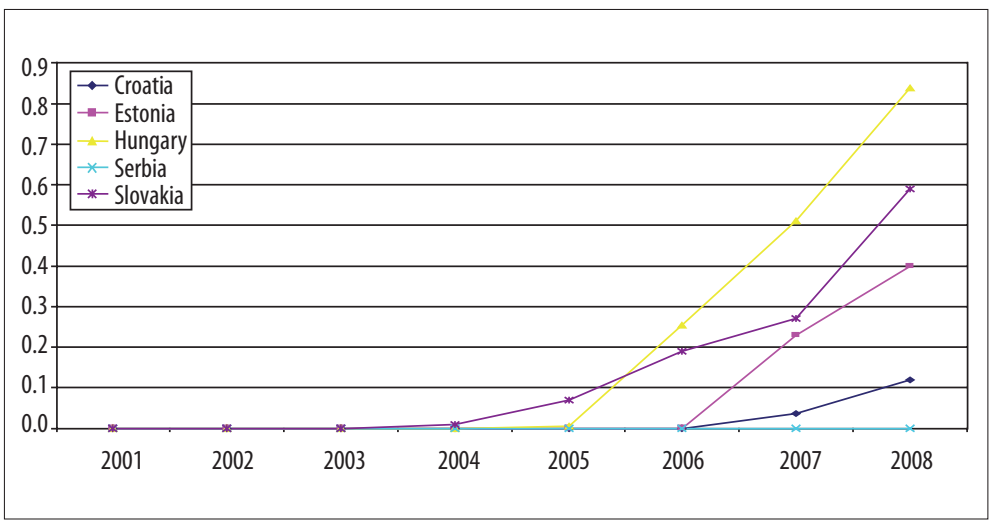

Figure 6. Adalimumab in selected CEE countries: number of pack per 1000 inhabitants.

of TNF-inhibitor therapy in all countries except Russia. The proportion of patients treated with rituximab is the highest in Slovakia, Serbia and Poland.

Data on utilization of RA biologic drugs over time are in most cases incomplete. This report only presents the analysis for countries where it was possible to derive necessary information. The graphs (Figures 4-6) show number of packs of biologic drugs used per 1,000 inhabitants in Croatia, Estonia, Hungary, Serbia, Slovakia and Slovenia during 2001-2008. Use of etanercept started after its re-launch in 2003. Hungary, Slovakia and Slovenia are the leading countries in etanercept use, joined since 2007 by Estonia. The use of infliximab increased more steadily and is highest in Hungary and Slovakia. Adalimumab was introduced after infliximab and etanercept, but its use was growing more rapidly in Slovenia, followed by Hungary, Slovakia and Estonia.
Determinants of access to biologic treatment in RA

\section{Pricing}

Pricing of pharmaceuticals is a complex process influenced by a number of factors. It should be noted however, that as pharmaceuticals are competing in a global market, and in particular in the EU with free movements of goods, they are priced within a narrow price band to avoid parallel trade. For example, the price index, using Poland as an index of 1, varies between 1-1.2 for infliximab, and 0.8-1.5 for etanercept and adalimumab (Table 5). It is difficult to discern a clear pattern, as the price differences are not systematic; for example, countries with lower level of health care expenditure do not necessarily have comparatively lower prices. The lowest prices were in Hungary, which belongs to the group of countries with the highest health care expenditure 
Table 5. Price comparison across countries: comparative price index (Poland=1).

\begin{tabular}{|c|c|c|c|c|c|c|c|c|c|c|}
\hline & Bulgaria & Croatia & Czech Rep & Estonia & Hungary & Poland & Romania & Serbia & Slovakia & Slovenia \\
\hline $\begin{array}{l}\text { Infliximab } \\
(\text { per } 0.003 \mathrm{~g})\end{array}$ & NA & 1.11 & 1.16 & 1.13 & 1.07 & 1.00 & 1.20 & 1.01 & 1.33 & 1.25 \\
\hline $\begin{array}{c}\text { Etanercept } \\
\text { (per } 0.025 \mathrm{~g} \text { ) }\end{array}$ & 0.97 & 1.03 & 1.29 & 1.04 & 0.82 & 1.00 & 1.10 & 0.96 & 1.46 & 1.08 \\
\hline $\begin{array}{l}\text { Adalimumab } \\
\text { (per } 0.040 \mathrm{~g} \text { ) }\end{array}$ & 1.05 & 1.08 & 1.24 & 1.15 & 0.87 & 1.00 & 1.14 & NA & 1.58 & 1.23 \\
\hline
\end{tabular}

Table 6. Affordability index of biological anti-RA drugs (Poland=1).

\begin{tabular}{ccccccccccc}
\hline & Bulgaria & Croatia & Czech & Estonia & Hungary & Poland & Romania & Serbia & Slovakia & Slovenia \\
\hline Infliximab & & 1.1 & 0.7 & 0.9 & 0.6 & 1.0 & 1.6 & 1.4 & 0.9 & 0.4 \\
\hline Etanercept & 1.9 & 1.0 & 0.8 & 0.8 & 0.5 & 1.0 & 1.7 & 1.4 & 1.0 & 0.4 \\
\hline Adalimumab & 1.3 & 1.0 & 0.8 & 1.0 & 0.5 & 1.0 & 1.6 & & 1.1 & 0.4 \\
\hline
\end{tabular}

per capita in the CEE region (Hungary, Slovenia, Slovakia and Czech Republic). In other countries from this group, the prices were the highest. Affordability index was the lowest in Slovenia (0.4), followed by Hungary, Czech Republic and Estonia, while countries with health care expenditures below 500 USD per capita (Bulgaria, Romania and Serbia) had the highest indexes (Table 6). The important question is whether and how much these differences affect access. The analysis of relevant data shows that while in some countries, such as Hungary, Slovenia, Slovakia and Czech Republic, high affordability may explain relatively high access to biologic treatment, the low affordability in Romania does not. Hence, the conclusion is that use of biologic RA treatment depends on and is influenced by price and health care expenditure level, but there are also differences among countries that cannot be easily explained by variation in affordability.

\section{Founding}

The inclusion in the reimbursement system is a very important criterion for introduction of and access to, innovative treatment. In the majority of CEE countries there is a formalized decision-making process in which clinical, economic and budget impact analyses play an important role. Within these processes it is also possible to define the eligible patient populations more restrictively than in the EMEA market access authorization. Control mechanisms exist in most countries.

In all countries, infliximab, etanercept, adalimumab and rituximab are included in the reimbursement system. With the exception of Bulgaria and Slovenia, biologic drugs are reimbursed at $100 \%$ in all countries. In Bulgaria, public payer covered $50 \%$ of etanercept and adalimumab costs, and $75 \%$ of rituximab cost. In Slovenia, public payer reimbursed $75 \%$ of biological drugs price, and $25 \%$ was covered by supplementary health insurance (almost all citizens benefit from supplementary insurance). However, in Slovenia reimbursement procedures lead to unequal access to all biological drugs - retail drugs can be prescribed to all eligible patients, while hospital drugs (intravenously administered biological drugs), due to the establishment of a fixed budget, are available only to a limited number of patients. Fixed budget for biologic drugs for each hospital is also set in Estonia.

There are large variations in the time of inclusion of RA biologic treatments into the national reimbursement systems. Infliximab, etanercept and adalimumab were introduced into the reimbursement system during 2000-2004 in the Czech Republic and Slovenia; in 2005 in Slovakia; in 2006 in Croatia and Poland; in 2007 in Estonia; and in 2009 in Bulgaria. In Hungary, infliximab and etanercept have been reimbursed since 2004, and adalimumab since 2006. Rituximab was included into the reimbursement system first in Poland (in 2006), and last in Bulgaria and Estonia (in 2009). Abatacept and tocilizumab are covered by public payer only in Slovakia, since 2008 and 2009, respectively. Analysis of the utilization of infliximab, etanercept, adalimumab and rituximab in selected CEE countries (Figures 4-6) reveals that inclusion into the reimbursement list is one of the strongest drivers for the use of RA innovative drugs. As a result of the reimbursement, a substantial (at least 2-fold) rise in utilization was observed.

\section{Health technology assessment}

All countries declared that health technology assessment (HTA), with clinical, economic and budget impact analyses, support decision-making in health care at all levels and has a strong influence on the use of innovative treatments. However, only a few countries (Hungary and Poland) have more formal HTA systems in place, while others are still in the early stages of implementing a national HTA body(s). As a result, there are only a few HTA evaluations of biological treatments in RA available [11-16,18]; not surprising, in view of the lack of country-specific data on cost of care and quality of life of RA patients.

In 2008, the Polish HTA agency published a recommendation on the use of infliximab as "initiating therapy", based on 
the evidence of equivalent efficacy of infliximab, etanercept and adalimumab, and lowest price of infliximab among the TNF-alfa inhibitors [11]. It was estimated that 2-year acquisition and administration costs of adalimumab, etanercept and infliximab was 26.5, 27.2 and $20.3 \mathrm{mln}$ EURO, respectively; however, no information was given about the population included. In the only published economic evaluation of TNF-alfa inhibitors in Poland [12], the lifetime costs for infliximab, etanercept and adalimumab administered in combination with methotrexate were 50519,57318 and 66095 EURO per patient, respectively. In this analysis, incremental outcomes (quality-adjusted life years, [QALYs]) in comparison to methotrexate were 0.653 (infliximab), 1.012 (etanercept), and 1.085 (adalimumab). The incremental cost effectiveness ratio (ICER) values compared to standard disease-modifying anti-rheumatic drugs (DMARDs) varied from 26,928 EURO/QALY (etanercept) to 33,205 EURO/QALY (adalimumab), and exceeded the cost-effectiveness threshold set in Poland ( $3 \times$ GDP, that is 19,358 EURO/QALY).

In a 2007 Hungarian HTA report [13], there was no significant difference in the efficacy and safety between the various TNF-alfa inhibitors presented. Under the given price structure and financing mechanisms, the most economically advantageous option was the $3 \mathrm{mg} / \mathrm{kg}$ infliximab therapy. The savings per RA case were 9,080 EURO compared to adalimumab, and 10,852 EURO, compared to etanercept in a 3-year time period considering the monitoring and administration related costs, as well as drug waste. The savings were noticeable from the first year of the infliximab therapy - 1,632 EURO (11\%) compared to adalimumab, and 2,252 EURO (15\%) compared to etanercept. The average yearly savings were $22 \%$ and 25\%, respectively. The ICER for the TNF-alfa inhibitors versus methotrexate was 24,486 EURO /QALY (infliximab) and 14,400-34,800 EURO/QALY (abatacept), and abatacept therapy was a dominant strategy compared to TNF-alfa inhibitors [15]. A 2006 economic evaluation of rituximab in the treatment of adults with RA who have had an inadequate response to TNF-alpha inhibitors, showed ICER of 27,258 EURO/QALY versus palliative treatment [16]. In Hungary, no cost-effectiveness threshold approved by National Health Insurance Foundation exists, however, the application of the threshold value of $3 \times \mathrm{GDP} / \mathrm{QALY}$ accepted in some countries [17] leads one to consider TNF-alpha inhibitors and rituximab to be cost-effective treatments in Hungary.

In Romania, only 1 economic analysis was published [18]. In the cost-effectiveness analysis, 2 alternatives were compared a sequence of treatment including either infliximab, etanercept or adalimumab, followed by rituximab, and a sequence of treatment including tocilizumab as first agent, followed by rituximab. The incremental cost-utility ratio (ICUR) was 14,717 EURO/QALY gained (CI: 9,357-20,076). The ICUR ratio was in line with other treatments reimbursed by the National Health Insurance agency.

In some of the cases presented above there is a direct link between the assessment and funding of technology.

\section{Treatment guidelines for the use of biologic therapy in $R A$}

Defining the eligibility criteria for biologic treatment strongly affects the access to therapies within countries, and thus creates the differences between them. Table 7 summarizes the recommendations guiding the use of biologic therapy in RA in selected CEE countries [19-29]. There are differences in status of guidelines - some are "scientific" (published by national Societies for Rheumatology), while others are "formal" (published by institutions responsible for reimbursement), as well as the year of revision in different countries. In order to determine potential factors influencing the access to biologic therapy, particular attention was paid to the recommended criteria for initiation of biologic therapy (prior treatment with DMARDs, as well as disease activity levels), and treatment response measurement.

In general, consensus from national guidelines recommend that TNF inhibition should be started following confirmed diagnosis of active RA and failure of treatment with traditional DMARDs, including methotrexate; however, the disease activity levels designated for initiation and/or cessation of TNF inhibitors, pattern and duration of previous DMARDs treatment differ. The Disease Activity Score, considering 28 different joints (DAS28) over 5.1, is commonly used to define highly active disease that could qualify for TNF inhibition treatment. In Romania, patients must also have 5 or more joints with active synovitis, and fulfill 2 of the following 3 criteria: morning stiffness lasting for over 60 minutes, erythrocyte sedimentation rate $(\mathrm{ESR})>28 \mathrm{~mm} / \mathrm{h}$, and C-reactive protein (CRP) $>20 \mathrm{mg} / \mathrm{l}$. In Croatia, DAS28 above 5.1 and HAQ 1.0-2.5 are required. In Estonia, a patient was qualified for treatment with TNF inhibitors when the following criteria were met: 6 or more joints with active synovitis, morning stiffness lasting for over 60 minutes or the joint-visceral form of RA plus ESR $<30 \mathrm{~mm} / \mathrm{h}$ or CRP $>25 \mathrm{mg} / \mathrm{l}$ or DAS $28>4.6$, provided that DAS value has been at that level for 2 months after the last parenteral administration of glucocorticosteroids. However, in Poland and Hungary, lower disease activity also qualifies for TNF inhibitors, providing that patients meet other requirements (e.g., in Hungary, radiologic progression). Poland requires presence of Still syndrome, uveitis, cryoglobulinemia or DAS28 above 3.7 in RA patients with dominating symptoms from lower limbs. In Slovakia, active disease with poor prognostic factors is necessary, although it is not clearly specified what are the implications of such status. Slovenia requires demonstration of persistent moderate disease activity (DAS28 $>4.2$ ) and at least 8 swollen joints.

In most countries, failure of at least 2 DMARDs qualifies for the consideration of TNF inhibitors treatment; however there are exceptions to this rule. For example, in Estonia, failure of combined therapy with 4 DMARDs is required, while in the Czech Republic, Hungary and Serbia it is sufficient to prove inefficacy (or intolerance) of 1 DMARD (methotrexate or leflunomide). Czech guidelines specify that in case of contraindications or intolerance of DMARDs, TNF inhibitors can be used without previous DMARDs treatment. The minimum time on previous DMARDs varies from 3 months in total (Hungary) to 6 months for each of 2 DMARDs (Poland); however, in most countries 6 months in total are required. In order for the TNF inhibitors treatment to continue unaltered, guidelines generally require demonstration of a response according to the European League Against Rheumatism (EULAR). EULAR response is defined as DAS28 $<3.2$ or DAS28 $<5.1$, and a decrease in DAS28 by at least 1.2 points. In Bulgaria, treatment must be altered if the patient fails to achieve at least a $50 \%$ reduction in number of swollen and 
Table 7. Recommendations from guidelines for the use of TNF inhibitors in RA in selected CEE countries.

\begin{tabular}{|c|c|c|c|c|c|c|c|c|c|c|}
\hline $\begin{array}{l}\text { Country } \\
\text { (year of the } \\
\text { guidelines } \\
\text { revision) }\end{array}$ & Status & $\begin{array}{l}\text { Disease } \\
\text { activity }\end{array}$ & $\begin{array}{l}\text { Previous } \\
\text { DMARDs } \\
\text { treatment }\end{array}$ & $\begin{array}{l}\text { Duration } \\
\text { of previous } \\
\text { DMARDs } \\
\text { treatment }\end{array}$ & $\begin{array}{l}1^{\text {st line }} \\
\text { biological } \\
\text { treatment } \\
\text { are TNF } \\
\text { inhibitor }\end{array}$ & $\begin{array}{l}\text { Improvement } \\
\text { measure }\end{array}$ & $\begin{array}{l}\text { Time period for } \\
\text { improvement }\end{array}$ & $\begin{array}{l}\text { Switching between } \\
\text { drugs due to inefficacy }\end{array}$ & $\begin{array}{l}2^{\text {nd }} \text { line } \\
\text { biological } \\
\text { drugs }\end{array}$ & $\begin{array}{c}3^{\text {rd line }} \\
\text { biological } \\
\text { drugs }\end{array}$ \\
\hline $\begin{array}{c}\text { Bulgaria (2009) } \\
\quad[19,20]\end{array}$ & $\begin{array}{l}\text { Recommendations } \\
\text { of Bulgarian NHIF }\end{array}$ & DAS28 $>5.1$ & $\begin{array}{c}\text { Two } \\
\text { DMARDS, } \\
\text { including } \\
\text { MTX (unless } \\
\text { contraindicated) }\end{array}$ & $\begin{array}{c}\text { Not } \\
\text { mentioned }\end{array}$ & Yes & $\begin{array}{c}\text { Number of swollen and } \\
\text { tender joints } \\
(>50 \% \text { reduction }), \\
\text { ESR }(<40 \mathrm{~mm}), \\
\operatorname{CRP}(<8 \mathrm{~g} / \mathrm{L} \text {, decreas of DAS } \\
28 \text { by at least } 1.6)\end{array}$ & 12 weeks & $\begin{array}{c}\text { Not } \\
\text { mentioned }\end{array}$ & $\begin{array}{l}\text { Other TNF- } \\
\text { inhibitor or } \\
\text { rituximab (after } \\
\text { at least one } \\
\text { TNFinhibitor } \\
\text { failure) }\end{array}$ & Not mentioned \\
\hline $\begin{array}{c}\text { Croatia (2006) } \\
\text { [22] }\end{array}$ & $\begin{array}{l}\text { Recommendations } \\
\text { of Croatian } \\
\text { Rheumatological } \\
\text { Association }\end{array}$ & $\begin{array}{c}\text { ACRI-III } \\
\text { /DAS28 } \\
>5.1, \mathrm{HAQ} \\
1-2.5)\end{array}$ & $\begin{array}{c}\text { Two } \\
\text { DMARDs, } \\
\text { including } \\
\text { MTX }\end{array}$ & $\begin{array}{l}6 \text { months (at } \\
\text { least } 2 \text { months } \\
\text { at target } \\
\text { therapeutic } \\
\text { dose ifitis not } \\
\text { limited by ADR } \\
\text { or }<6 \text { months if } \\
\text { the interruption } \\
\text { caused by ADR }\end{array}$ & f & $\begin{array}{c}\text { Decrease of DAS28 } \\
\text { by at least } 1.2 \text { or } \\
\text { a reduction DAS } 28 \leq 3.2 \text { after } \\
3 \text { months }\end{array}$ & 12 weeks & $\begin{array}{c}\text { Not } \\
\text { mentioned }\end{array}$ & $\begin{array}{c}\text { Not } \\
\text { mentioned }\end{array}$ & $\begin{array}{c}\text { Not } \\
\text { mentioned }\end{array}$ \\
\hline $\begin{array}{c}\text { Czech (2007) } \\
\text { [21] }\end{array}$ & $\begin{array}{l}\text { Recommendations } \\
\text { of Czech } \\
\text { Rheumatological } \\
\text { Association }\end{array}$ & DAS $28>5.1$ & $\begin{array}{c}\text { MTX or } \\
\text { leflunomide or } \\
\text { sulfasalzin in } \\
\text { the case of MTX } \\
\text { intolerance or } \\
\text { contraindications. } \\
\text { In the case of } \\
\text { containdications } \\
\text { or intolerance } \\
\text { of DMARDs TNF } \\
\text { inhibitor can be } \\
\text { used without } \\
\text { previous DMARDS } \\
\text { treatment }\end{array}$ & . & $\begin{array}{l}\text { Yes; in the } \\
\text { case of } \\
\text { containdications } \\
\text { or intolerance } \\
\text { of TNF } \\
\text { inhibitors } \\
\text { rituximab can } \\
\text { be used as } 1 \\
\text { line treatment }\end{array}$ & $\begin{array}{c}\text { Decrease of DAS28 } \\
\text { by at least } 1.2, \\
\text { radiographic monitoring }\end{array}$ & $\begin{array}{l}12 \text { weeks, } \\
\text { than every } 8 \text { weeks }\end{array}$ & Yes & $\begin{array}{l}\text { other TNF- } \\
\text { inhibitor or } \\
\text { rituximab } \\
\text { (after at } \\
\text { least one } \\
\text { TNF inhibitor } \\
\text { failure) }\end{array}$ & $\begin{array}{c}\text { Not } \\
\text { mentioned }\end{array}$ \\
\hline $\begin{array}{c}\text { Estonia } \\
\text { [23] }\end{array}$ & $\begin{array}{l}\text { Recommendation } \\
\text { of Estonian } \\
\text { Health } \\
\text { Insurance } \\
\text { Fund } \\
\end{array}$ & $\begin{array}{l}6 \text { or more } \\
\text { joints with } \\
\text { active synovitis, } \\
\text { morning } \\
\text { stiffness for } \\
\text { over } 60 \text { min } \\
\text { or the joint- } \\
\text { visceral form } \\
\text { of RA plus } \\
\text { ERS }>30 \text { mm/h } \\
\text { or CRP }>25 \\
\text { mg/l or DAS } 28 \\
>4.6 \text { provided } \\
\text { that it has been } \\
\text { at two months } \\
\text { since the last } \\
\text { parenteral } \\
\text { administration } \\
\text { of glucocorticos }\end{array}$ & $\begin{array}{c}\text { Combined } \\
\text { treatment } \\
\text { with } \\
\text { 4DMARDs, } \\
\text { including } \\
\text { MTX (unless } \\
\text { contraindicated) } \\
\\
\end{array}$ & $\begin{array}{l}6 \text { months } \\
\text { altogether with } \\
\text { all previous } \\
\text { DMARDs }\end{array}$ & $\begin{array}{c}\text { Not } \\
\text { mentioned }\end{array}$ & $\begin{array}{l}\text { Decrease of DAS28 } \\
\text { by at least } 1.2 \text { or } \\
\text { achievement of ACR50 or } \\
\text { good treatment response } \\
\text { in joint-visceral form of RA } \\
\text { according to experts opinion }\end{array}$ & 3 months & $\begin{array}{l}\text { Other aTNF } \\
\text { or rituximab }\end{array}$ & Rituximab & $\begin{array}{c}\text { Not } \\
\text { mentioned }\end{array}$ \\
\hline $\begin{array}{c}\text { Hungary (2008) } \\
\text { [24] }\end{array}$ & $\begin{array}{l}\text { The professional } \\
\text { protocol of the } \\
\text { MoH on the use of } \\
\text { biological therapy } \\
\text { in inflammatory } \\
\text { rheumatological } \\
\text { diseases }\end{array}$ & $\begin{array}{l}\text { DAS } 28>5.1 \\
\text { or radiological } \\
\text { progression* }\end{array}$ & $\begin{array}{l}20 \mathrm{mg} / \text { week } \\
\text { MTX or } 20 \mathrm{mg} / \mathrm{d} \\
\text { leflunomide (or } \\
\text { lower doses in } \\
\text { combination } \\
\text { therapy) }\end{array}$ & 3 months & Yes & $\begin{array}{c}\text { Decrease of DAS28 } \\
\text { by at least 1.2, } \\
\text { radiographic monitoring }\end{array}$ & 3 months & Yes & $\begin{array}{l}\text { Rituximab } \\
\text { or abatacept } \\
\text { (after at } \\
\text { least one } \\
\text { TNF inhibitor } \\
\text { failure) }\end{array}$ & $\begin{array}{c}\text { Not } \\
\text { mentioned }\end{array}$ \\
\hline
\end{tabular}


Table 7 continued. Recommendations from guidelines for the use of TNF inhibitors in RA in selected CEE countries.

\begin{tabular}{|c|c|c|c|c|c|c|c|c|c|c|}
\hline $\begin{array}{l}\text { Country } \\
\text { (year of the } \\
\text { guidelines } \\
\text { revision) }\end{array}$ & Status & $\begin{array}{l}\text { Disease } \\
\text { activity }\end{array}$ & $\begin{array}{l}\text { Previous } \\
\text { DMARDs } \\
\text { treatment }\end{array}$ & $\begin{array}{l}\text { Duration } \\
\text { of previous } \\
\text { DMARDs } \\
\text { treatment }\end{array}$ & $\begin{array}{l}1^{\text {st line }} \\
\text { biological } \\
\text { treatment } \\
\text { are TNF } \\
\text { inhibitor }\end{array}$ & $\begin{array}{l}\text { Improvement } \\
\text { measure }\end{array}$ & $\begin{array}{l}\text { Time period for } \\
\text { improvement }\end{array}$ & $\begin{array}{l}\text { Switching between } \\
\text { drugs due to inefficacy }\end{array}$ & $\begin{array}{l}2^{\text {nd }} \text { line } \\
\text { biological } \\
\text { drugs }\end{array}$ & $\begin{array}{c}3^{\text {rd line }} \\
\text { biological } \\
\text { drugs }\end{array}$ \\
\hline $\begin{array}{c}\text { Poland (2009) } \\
\text { [25] }\end{array}$ & $\begin{array}{l}\text { NHFTherapeutic } \\
\text { Health } \\
\text { Programme: } \\
\text { treatment of } \\
\text { rheumatiod } \\
\text { arthritis and } \\
\text { juvenile arthritis } \\
\text { with aggresive } \\
\text { progression } \\
\end{array}$ & $\begin{array}{l}\text { DAS28 >5.1 } \\
\text { confirmed on } \\
\text { at least two } \\
\text { occasions } \\
\text { or DAS28 } \\
>3.7 \text { in RA } \\
\text { patients with } \\
\text { dominating } \\
\text { symptoms from } \\
\text { lower limbs or } \\
\text { independently } \\
\text { of DAS28 in } \\
\text { the presence of } \\
\text { Still syndrom, } \\
\text { uveitis, } \\
\text { cryoglobu- } \\
\text { inemia }\end{array}$ & $\begin{array}{l}\text { Two DMARDS, } \\
\text { including } \\
\text { MTX (unless } \\
\text { contraindicated) } \\
\end{array}$ & $\begin{array}{l}6 \text { months each } \\
\text { DMARD with } 3 \\
\text { months of MTX } \\
\text { at maximum } \\
\text { dose, unless } \\
\text { significant } \\
\text { toxicity has } \\
\text { limited the } \\
\text { dose or } \\
\text { duration of } \\
\text { treatment. } \\
\text { In patients } \\
\text { with risk of } \\
\text { disablement or } \\
\text { death therapy } \\
\text { with TNF- } \\
\text { inhibitors can } \\
\text { be started } \\
\text { before ending } \\
\text { the obligatory } \\
\text { tria }\end{array}$ & $\begin{array}{l}\text { Yes; initiating } \\
\text { therapy } \\
\text { defined } \\
\text { by NHF } \\
\text { (treatment } \\
\text { should be } \\
\text { initiated with } \\
\text { the least } \\
\text { expensive } \\
\text { drug, taking } \\
\text { into account } \\
\text { administration } \\
\text { costs, required } \\
\text { dose and } \\
\text { product price } \\
\text { per dose); } \\
\text { changing } \\
\text { of initiating } \\
\text { therapyneeds } \\
\text { approval from } \\
\text { Coordinating } \\
\text { Comm }\end{array}$ & $\begin{array}{c}\text { Decrease of DAS28 } \\
\text { by at least } 1.2\end{array}$ & 3 months & $\begin{array}{l}\text { Yes (no more } \\
\text { than two TNF-inhibitor } \\
\text { in one patient) }\end{array}$ & $\begin{array}{l}\text { Other TNF- } \\
\text { inhibitor or } \\
\text { rituximab (after } \\
\text { at least one } \\
\text { TNF inhibitor } \\
\text { failure) } \\
\text { provided that } \\
\text { cost criteria set } \\
\text { for initiating } \\
\text { therapy have } \\
\text { been met }\end{array}$ & Rituximab \\
\hline $\begin{array}{l}\text { Romania (2007) } \\
\text { [26] }\end{array}$ & $\begin{array}{l}\text { NHl order } \\
\text { approving the } \\
\text { protocol of practice } \\
\text { on prescribing, } \\
\text { monitoring and } \\
\text { settlement drugs } \\
\text { for insured RA } \\
\text { patients }\end{array}$ & $\begin{array}{l}\text { DAS28 }>5.1 \\
\text { and } 5 \text { or more } \\
\text { e joints with } \\
\text { active synovitis } \\
\text { plus two of } \\
\text { the following } \\
\text { three criteria: } \\
\text { morning } \\
\text { stiffness for } \\
\text { over } 60 \text { min., } \\
\text { ESR }>28 \mathrm{mg} / \mathrm{L} \text {, } \\
\text { CRP }>20 \mathrm{mg} / \mathrm{L}\end{array}$ & $\begin{array}{l}\text { Two DMARDS, } \\
\text { including } \\
\text { MTX (unless } \\
\text { contraindicated) }\end{array}$ & $\begin{array}{l}12 \text { weeks each } \\
\text { DMARD }\end{array}$ & Yes & $\begin{array}{l}\text { Number of swollen and } \\
\text { tender joints, ESR, CRP, } \\
\text { decrease of DAS28 by at } \\
\text { least } 0.6\end{array}$ & 12 weeks & Yes & $\begin{array}{l}\text { Other } \\
\text { TNF-inhibitor or } \\
\text { rituximab (after } \\
\text { at least one } \\
\text { TNF inhibitor } \\
\text { failure) }\end{array}$ & $\begin{array}{c}\text { Not } \\
\text { mentioned }\end{array}$ \\
\hline $\begin{array}{c}\text { Serbia (2009) } \\
\text { [27] }\end{array}$ & $\begin{array}{l}\text { General } \\
\text { medical approach } \\
\text { published in local } \\
\text { medical journal; }\end{array}$ & DAS28 $>5.1$ & $\begin{array}{c}\text { MTX } \\
\text { (or other } \\
\text { DMARD if } \\
\text { intolerant) }\end{array}$ & $\begin{array}{l}6 \text { month } \\
\text { (or limiting } \\
\text { toxicity) }\end{array}$ & Yes & $\begin{array}{l}\text { DAS improvement } \\
\text { by } 1.2\end{array}$ & 6 months & $\begin{array}{l}\text { No TNF swich; } \\
\text { swich to rituximab } \\
\text { or other non anti TNF }\end{array}$ & Rituximab & $\begin{array}{c}\text { Not } \\
\text { mentioned }\end{array}$ \\
\hline $\begin{array}{l}\text { Slovakia (2005; } \\
\text { assessment of } \\
\text { response-2009) } \\
{[28,29]}\end{array}$ & $\begin{array}{l}\text { General medical } \\
\text { approach } \\
\text { published in local } \\
\text { medical journal; } \\
\text { MoH Regulation } \\
\text { on Disease activity } \\
\text { and joint function } \\
\text { impairment } \\
\text { assessment in } \\
\text { patients with RA }\end{array}$ & $\begin{array}{l}\text { Active disease } \\
\text { with poor } \\
\text { prognostic } \\
\text { factors } \\
\text { y }\end{array}$ & $\begin{array}{l}\text { Two DMARDS, } \\
\text { including MTX }\end{array}$ & $\begin{array}{c}\text { Not } \\
\text { mentioned }\end{array}$ & Yes & $\begin{array}{l}\text { DAS } 28 \text { (evaluation of } \\
\text { response according to } \\
\text { EULAR); HAQ (decrese/ } \\
\text { increase by } 0.22 \text { is considered } \\
\text { the least significant change) }\end{array}$ & $12-16$ weeks & Yes & Adalimumab & $\begin{array}{c}\text { Not } \\
\text { mentioned }\end{array}$ \\
\hline
\end{tabular}


Table 7 continued. Recommendations from guidelines for the use of TNF inhibitors in RA in selected CEE countries.

\begin{tabular}{|c|c|c|c|c|c|c|c|c|c|c|}
\hline $\begin{array}{l}\text { Country } \\
\text { (year of the } \\
\text { guidelines } \\
\text { revision) }\end{array}$ & Status & $\begin{array}{l}\text { Disease } \\
\text { activity }\end{array}$ & $\begin{array}{l}\text { Previous } \\
\text { DMARDs } \\
\text { treatment }\end{array}$ & $\begin{array}{l}\text { Duration } \\
\text { of previous } \\
\text { DMARDs } \\
\text { treatment }\end{array}$ & $\begin{array}{c}1^{\text {st line }} \\
\text { biological } \\
\text { treatment } \\
\text { are TNF } \\
\text { inhibitor }\end{array}$ & $\begin{array}{l}\text { Improvement } \\
\text { measure }\end{array}$ & $\begin{array}{l}\text { Time period for } \\
\text { improvement }\end{array}$ & $\begin{array}{l}\text { Switching between } \\
\text { drugs due to inefficacy }\end{array}$ & $\begin{array}{c}2^{\text {nd }} \text { line } \\
\text { biological } \\
\text { drugs }\end{array}$ & $\begin{array}{c}3^{\text {rd line }} \\
\text { biological } \\
\text { drugs }\end{array}$ \\
\hline Slovenia & & $\begin{array}{c}\text { DAS28 }>4.2, \\
\text { number of } \\
\text { swollen } \\
\text { joints }>8 \\
\text { (in addition } \\
\text { to } 28 \text { joints } \\
\text { assessed for } \\
\text { DAS28 also } \\
\text { ankles and MTP } \\
\text { joints } \\
\text { should be } \\
\text { assessed) }\end{array}$ & $\begin{array}{l}\text { Two DMARDS } \\
\text { (MTX } 20 \text { mg/week } \\
\text { or lefluniomide } \\
\text { or combination } \\
\text { of MTX and } \\
\text { other DMARDs) } \\
\text { or at least two } \\
\text { of the following } \\
\text { treatments if } \\
\text { MTX was stopped } \\
\text { due to ADR: } \\
\text { leflunomide, } \\
\text { sulfasalazine, } \\
\text { cyclosprine } \\
\text { A, hydroxy- } \\
\text { chlorochine, } \\
\text { parental salts } \\
\text { of gold }\end{array}$ & $\begin{array}{l}3 \text { months each } \\
\text { DMARD or } 4 \\
\text { months each } \\
\text { DMARD if MTX } \\
\text { wasstopped } \\
\text { dues to ADR } \\
\end{array}$ & $\begin{array}{c}\text { Not } \\
\text { mentioned }\end{array}$ & $\begin{array}{c}\text { DAS improvement } \\
\text { by } 1.2\end{array}$ & $\begin{array}{l}\text { Criterion should be } \\
\text { met twice in } 6 \text { months }\end{array}$ & Not mentioned & $\begin{array}{c}\text { Not } \\
\text { mentioned }\end{array}$ & $\begin{array}{c}\text { Not } \\
\text { mentioned }\end{array}$ \\
\hline
\end{tabular}

* Larsen score or Ratingen Score or Modified Sharp Score are required. ADR - adverse drug reaction; CRP - C-reactive protein; DAS - Disease Activity Score; DMARD - Disease Modifying Drug; ESR - erythrocyte sedimentation rate; MTX - methotrexate; NHI - National Health Insurance.

tender joints, ESR $<40 \mathrm{~mm}, \mathrm{CRP}<8 \mathrm{~g} / \mathrm{L}$, and decrease of DAS 28 by at least 1.6 points. In Estonia, decrease of DAS28 by at least 1.2, achievement of ACR50, or good treatment response in joint-visceral form of RA according to experts' opinion is required. In Romania, as an improvement measure, the reduction in number of swollen and tender joints, ESR, CRP and decrease of DAS28 by at least 0.6 is used.

In summary, it is clear that despite many similarities, there are differences in criteria used in different countries for initiation of biologic therapy and assessment of treatment response. The relationship between these criteria and drug usage estimates presented shows that in countries where the recommendations are more restrictive (e.g., Poland and Estonia), lower usage levels can be observed. It is also apparent that other factors may influence access to biological therapies, such as level of recognition of guidelines and availability of care.

\section{Other factors}

Other factors that influence usage of biologics are limitations in number of prescribers, administrative hurdles and availability of care. In most CEE countries, prescription of biologics is restricted to specialists working in centers of excellence, and can require prior authorization (e.g., consilium decision in Estonia, Central National Expert Committee of the HIF in Serbia). This fact, combined with the slow referral process (lack of specialists, long waiting times prior to consultation), would partly explain the low usage of biologic RA therapies.

Furthermore, RA patients must be first entered into a register, and then there are specific procedures for reporting treatment outcomes. In Poland, treatment should be initiated with the least expensive drug, taking into account administration costs, required dose and product price per dose. Changing of initiating therapy requires approval from the Coordinating Committee.

\section{Discussion}

This study describes current RA policies in CEE countries (8 EU member states, plus Croatia, Serbia and Russia) on the basis of the best available factual information and stakeholders' opinions. We address the burden of the disease in terms of epidemiology and cost, the use of biologic treatment over time, the proportion of RA patients treated, hurdles that affect usage, and differences between countries. Significant efforts were made to consult a range of RA stakeholder groups in the preparation of each country report. For countries with no data or insufficient data, no assumptions/imputations were made.

The scope of previously published series of publications $[30,31]$ is broader. Those reports provide information on the burden of RA and patient access to biologic treatments in 30 European countries (27 EU member states plus Iceland, Norway and Switzerland), as well as Turkey. However, the analysis of situations in CEE countries in these reports is, in comparison to our study, less detailed, in particular in the areas of clinical practice and organization of care. Hence, the current study and previous studies complement each other.

As shown in our study, 1-5\% of all RA patients in CEE countries are treated with biologic drugs. This is in agreement with results of previous publications [30,31], although there are differences in methods used for calculations. We combined the information on the number of patients actually treated in each country, derived from registries with 
estimated RA prevalence. In the above-mentioned publications, sales data from IMS (volume and value), average annual dose per patient and drug, as well as estimated RA prevalence in each country were used.

Data on cost of RA in CEE are limited to only 2 countries. In contrast to previously published reports, we did not make assumptions about countries with similar GDP and similar health care spending per capita. This approach was chosen to present information gaps and to show that there should be more investment in data collection for those parameters that are thought to differ most from country to country.

\section{Conclusions}

In CEE countries, $1-5 \%$ of all RA patients are treated with biologic drugs. In comparison, in Western Europe (the old EU plus Iceland, Norway, Switzerland) the average usage is $11-12 \%$, ranging from less than $5 \%$ in Austria, up to $30 \%$ in Norway [30]. In Germany, Italy and the United Kingdom the usage of biologic RA drugs is between $5-10 \%$. To a large extent, general economic conditions explain the large differences between Western and CEE countries. However, limited usage of biologics in CEE and differences between countries of this region are a consequence not only of macroeconomic conditions, but also of restrictive treatment guidelines, administrative hurdles and limited access to specialists.

This study reveals huge gaps in basic information needed for evidence-based medical decision making. Investments need to be made in the collection of relevant data to ensure that guidelines for the use of biologic drugs in RA in CEE are based on evidence rather than economic conditions.

\section{Aknowledgments}

The project was carried out with full transparency and without any influence from its funding sources.

\section{REFERENCES:}

1. Sokka T, Kautiainen H, Pincus T et al: Disparities in rheumatoid arthritis disease activity according to gross domestic product in 25 countries in the QUEST-RA database. Ann Rheum Dis, 2009; 68(11): 1666-72

2. Hanova P, Pavelka K, Dostal C et al: Epidemiology of rheumatoid arthritis, juvenile idiopathic arthritis and gout in two regions of the Czech Republic in a descriptive population-based survey in 2002-2003. Clin Exp Rheumatol, 2006; 24(4): 499-507

3. Otsa K, Tammaru M, Vorobjov S et al: The prevalence of rheumatoid arthritis (RA) in Harju County, Estonia. EULAR 2009; Abstract FRI0517

4. Kiss CG, Lovei C, Suto G et al: Prevalence of rheumatoid arthritis in the South-Transdanubian region of Hungary based on a representative survey of 10,000 inhabitants. J Rheumatol, 2005; 32(9): 1688-90

5. Péntek M, Kobelt G, Czirják L et al: Costs of rheumatoid arthritis in Hungary. J Rheumatol, 2007; 34(6): 1437-38

6. Jankovic S, Kostic M, Radosavljevic M, Jovanovic S: Cost of rheumatoid arthritis in a Balcan Country (Serbia). East European Politics\& Societes, http://eep.sagepub.com

7. Guillemin F, Durieux S, Daurés JP et al: Costs of rheumatoid arthritis in France: A multicenter study of 1109 patients managed by hospitalbased rheumatologists. J Rheumatol, 2004; 31: 1297-304

8. Verstappen SM, Verkleij H, Bijlsma JW et al: Determinants of direct costs in Dutch rheumatoid arthritis patients. Ann Rheum Dis, 2004; 63: $817-24$

9. Westhovens R, Boonen A, Verbruggen L et al: Healthcare consumption and direct costs of rheumatoid arthritis in Belgium. Clin Rheumatol, 2005 ; $24: 615-19$
10. Hulsemann JL, Ruof J, Zeidler H, Mittendorf T: Costs in rheumatology: results and lessons learned from "Hannover Costing Study". Rheumatol Int, 2006; 26: 704-11

11. NHF Resolution No 52/15/2008, 16.Oct 2008, concerning reimbursement of etanercept (Enbrel), adalimumab (Humira) and infliximab (Remicade) within the framework of therapeutic programme: "Treatment of rheumatoid arthritis " (in Polish) http://www.aotm.gov.pl/assets/files/ rada/uchwala_rk_aotm_52_15_2008_etanercept_Enbrel_adalimumab_Humira_ infliksimab_Remicade.pdf

12. Kaczor M, Wójcik R: An economic analysis of TNF-alpha anatgonists for rheumatoid arthritis. (Polish) Reumatologia, 2007; 5: 268-75 (in Polish)

13. Brodszky V, Péntek M, Májer I et al: Economic evaluation of the first TNF-alpha inhibitor therapy in patients with rheumatoid arthritis. Technology Assessment Report September 2007, http://hecon.uni-corvinus. hu/download/english/publ/hecon_research_23_eng.pdf

14. Májer I, Péntek M, Brodszky V, Gulácsi L: Health economics modelling: cost, effectiveness and cost-effectiveness of biological agents in patients with rheumatoid arthritis with particular emphasis on infliximab (Remicade) therapy. Technology Assessment Report June 2006. http://hecon.uni-corvinus.hu/download/english/publ/hecon_research_19.pdf

15. Brodszky V, Péntek M, Májer I et al: Abatacept in the treatment of rheumatoid arthritis; systematic review and economic evaluation. Technology Assessment Report June 2007. http://hecon.uni-corvinus.hu/download/ english/publ/hecon_research_22_eng.pdf

16. Brodszky V, Péntek M, Kárpáti K et al: Economic evaluation of rituximab in the treatment of rheumatoid arthritis in Hungary. Farmakoekonomika, 2008; 12(1): 10-16

17. Tan-Torres Edejer $\mathrm{T}$ et al: Choosing intervention that are cost-effective (WHO-CHOICE), 2003

18. Ansuta I, Baculea S, Szkultecka-Debek M: Cost-effectiveness evaluation of tocilizumab in Romanian health care system. Management in Health, 2009; 3: 7-10

19. NHIF requirements concerning protocols for rheumatoid arthritis treatment with rituximab (in Bulgarian). http://www.nhif.bg/downloads/ iziskvania_RA_Rituximab-21-09-09.doc

20. NHIF requirements concerning protocols for rheumatoid arthritis, psoriatic arthritis and juvenile arthritis treatment with anti-cytokine drugs: adalimumab, etanercept (in Bulgarian). http://www.nhif.bg/downloads/ iziskvania_Revmatoiden artrit anticitokini-01-09-09.doc

21. Bečvář R, Vencovský J, Němec P et al: Recommendations of Czech Rheumatological Association for the treatment of rheumatoid arthritis. Efficacy and treatment strategies. Čes revmatologie, Praha, 2007; 15(2): 73-90 (in Czech)

22. Čurković, B, Babić-Naglić Đ, Morović-Vergles J et al: Proposal for antiTNFalpha therapy in adult patients with rheumatoid arthritis. Reumatizam, 2007; 54(1): 16-19 (in Croatian)

23. Estonian Health Insurance Fund List, www.riigiteataja.ee/ert/act. $j p$ ? $i d=13231527$

24. The professional protocol of the Ministry of Health on the use of biological therapy in inflammatory rheumatological diseases. Egészségügyi Közlöny, 2008; 9: 2811-46 (in Hungarian)

25. Therapeutic Health Programme 2009. Treatment of rheumatoid arthritis and juvenile arthritis with aggressive progression. Attachment No 13 to Regulation of NHF Director from Sept 15, 2009 (in Polish). http:// www.nfz-krakow.pl/UserFiles/Leczenie \% 20RZS\% $20 i \%$ 20MIZS.pdf

26. NHI order approving the protocol of practice on prescribing, monitoring and settlement drugs for insured RA patients (in Romanian). http://www.cnas.ro/pdf/ordin221mai07.pdf

27. Damjanov N, Vojnović J: Biologic therapy of rheumatoid arthritis. Srpski arhiv za celokupno lekarstvo, 2009; 137(3-4): 205-10 (in Serbian)

28. Rovensky J, Rybar I, Mičekova D et al: Pharmacotherapeutic approaches for rheumatoid arthritis. Via pract, 2005; 2(2): 66-74 (in Slovakian)

29. Ministry of Health Regulation on Disease activity and joint function impairment assessment in patients with RA (in Slovakian). http://www. health.gov.sk/redsys/rsi.nsf/0/298af39beb3c4a18c12575d2003305d6/\$FILE/ vestnik_25_2009.pdf

30. Kobelt G, Kasteng F: Access to innovative treatments in rheumatoid arthritis in Europe. A report prepared for the European Federation of Pharmaceutical Industry Associations (EFPIA). October 2009. http://www. lif.se/cs/Publik\% 20webb/Sidinnehall/Publik_Dokument/Pressmeddelanden/ Access \% 20to\% 20RA \% 20Treatments \% 200ctober\% 202009.pdf

31. Jönsson B, Kobelt G, Smolen J: The burden of rheumatoid arthritis and access to treatment: uptake of new therapies. Eur J Health Econ, 2008; 8(Suppl.2): S33-106 